\title{
MENINGKATKAN KEMAMPUAN PEMECAHAN MASALAH MATEMATIKA MELALUI PENERAPAN MODEL PEMBELAJARAN PROBLEM BASED LEARNING (PBL) BERBANTUAN MEDIA REALIA PADA SISWA KELAS IV SD
}

\author{
Oktafrianto $^{1}$, Stefanus C Relmasira ${ }^{2}$, Agustina Tyas Asri Hardini ${ }^{3}$ \\ 1,2,3 PGSD FKIP Universitas Kristen Satya Wacana \\ Salatiga, Indonesia \\ e-mail: 292014022@student.uksw.edu ${ }^{1}$, Stefanus.relmasira@staff.uksw.edu² \\ Tyas.asri@staff.uksw.edu ${ }^{3}$
}

\begin{abstract}
Abstrak
Penelitian ini dilatar belakangi oleh keterampilan pemecahan masalah siswa yang masih rendah di SD Negeri Sidorejo Kidul 02 pada mata pelajaran Matematika. Tujuan penelitian untuk meningkatkan keterampilan pemecahan masalah siswa pada mata pelajaran Matematika melalui penerapan pembelajaran Problem Based Learning. Jenis penelitian menggunakan Penelitian Tindakan Kelas (PTK). Teknik pengumpulan data yaitu observasi dan tes hasil belajar. Subjek penelitian adalah siswa kelas IV SD Negeri Sidorejo Kidul 02 yang berjumlah 23. Alat pengumpulan data menggunakan lembar observasi, soal-soal tes kemudian dianalisis dengan data deskriptif kuantitatif. Hasil penelitian menunjukkan peningkatan persentase keterampilan pemecahan masalah siswa yang mencapai KKM pada siklus I meningkat dari 9 menjadi 15 peserta didik dengan rata-rata 74,21 . Pada siklus II siswa yang mencapai KKM mencapai 15 orang dengan rata-rata 82.86 . Aktivitas siswa juga mengalami peningkatan dari $80 \%$ disiklus I meningkat menjadi $100 \%$ pada siklus II. begitu juga dengan aktivitas guru. Pada siklus I menunjukkan presentase $75 \%$ meningkat menjadi $100 \%$ pada siklus II. Peningkatan ini terjadi karena siswa mulai memahami konsep pemecahan masalah Matematika. Dan guru menggunakan media realia yang dapat membatu siswa memahami konsep pemecahan masalah Matematika melalui langkah-langkah pembelajaran Problem Based Learning. Siswa lebih antusias dan aktif mengikuti setiap proses pembelajaran, lebih berani di dalam menyampaikan gagasan dan melakukan kegiatan tanya jawab bersama guru.
\end{abstract}

Kata Kunci: Keterampilan Pemecahan Masalah, Matematika, Problem Based Learning, Media Realia

\begin{abstract}
This research was motivated by the problem solving skills of students who were still low in SD Negeri Sidorejo Kidul 02 on Mathematics. The purpose of the study was to improve students' problem solving skills in Mathematics through the application of Problem Based Learning. This type of research uses Classroom Action Research (CAR). Data collection techniques are observation and test results. The research subjects were fourth grade students of SD Negeri Sidorejo Kidul 02 which numbered 23. The tools for collecting data using observation sheets, test questions were then analyzed with quantitative descriptive data. The results showed an increase in the percentage of problem solving skills of students who achieved KKM in the first cycle increased from 9 to 15 students with an average of 74.21. In the second cycle students who reached KKM reached 15 people with an average of 82.86. Student activities also experienced an increase of $80 \%$ in cycle I increasing to $100 \%$ in cycle II. as well as teacher activities. In the first cycle, the percentage of $75 \%$ increased to $100 \%$ in the second cycle. This increase occurs because students begin to understand the concept of solving mathematical problems. And the teacher uses realia media that can help students understand the concepts of mathematical problem solving through learning steps of Problem Based Learning. Students are more enthusiastic and actively participate in each learning process, more courageous in conveying ideas and conducting question and answer activities with the teacher.
\end{abstract}

Keywords: Problem Solving Skills, Mathematics, Problem Based Learning, Media Realia 


\section{Pendahuluan}

Matematika merupakan mata pelajaran yang diajarkan di semua jenjang pendidikan. Menurut Rahmadani \& Anugraheni (2017:243) Matematika merupakan disiplin ilmu yang dapat meningkatkan kemampuan berfikir, berargumentas, memberikan konstribusi ilmu untuk menyelesaikan masalah dalam kehidupan sehari hari. Adapun tujuan pembelajaran Matematika di sekolah dasar menurut Permendiknas No 21 Tahun 2016 meliputi: (1) Mengkomunikasikan gagasan dengan simbol, tabel, diagram atau media lain untuk memperjelas keadaan atau masalah, (2) Memiliki sikap menghargai kegunaan Matematika dalam kehidupan, yaitu memiliki rasa ingin tahu, perhatian dalam mempelajari Matematika, (3) Ulet dan percaya diri dalam pemecahan masalah. Maka dari itu pemecahan masalah Matematika sangatlah penting dipelajari guna membimbing siswa untuk memecahkan masalah di kehidupan sehari hari, bahkan dapat digunakan ke dalam dunia kerja nantinya.

Proses pemecaham masalah Matematika yang diajarkan dapat menggunakan pendekatan scientific. Pendekatan "scientific" merupakan sebuah kerangka ilmiah dalam pembelajaran Kurikulum 2013 yang terdiri dari aktivitas mengamati, menanya, mencoba, menganalisis dan mengkomunikasikan. Menurut Faizah (2015:28) Kondisi pembelajaran yang diharapkan dari pendekatan scientific adalah mendorong siswa dalam mencari tahu dari berbagai sumber melalui observasi, bukan hanya diberi tahu, maka dari itu guru perlu mempertimbangakan rancangan ketrampilan pemecahan masalah yang sejalan dengan pendekatan saintifik. Dengan pendekatan scientific proses pemecahan masalah akan mudah dipelajari dan pembelajaran akan lebih bermakna serta sisitematis, sehingga tujuan pembelajaran akan tercapai. Pemecahan masalah juga bagian dari kurikulum Matematika yang tidak terpisahkan. Hal ini dikarenakan siswa akan memperoleh pengalaman dalam menggunakan pengetahuan serta keterampilan yang dimiliki untuk menyelesaikan soal yang tidak rutin. Sependapat dengan pernyataan tersebut, Lencher (Hartono, 2014:3) mendefinisikan pemecahan masalah dalam Matematika sebagai proses menerapkan pengetahuan Matematika yang telah diperoleh sebelumnya ke dalam situasi baru yang belum dikenal.

Proses pemecaham masalah harus diterapkan dari jenjang terendah yaitu jenjang sekolah dasar. Karena pada jenjang ini akan membuat konsep pemecahan masalah akan tertanam pada diri siswa hingga jenjang-jenjang berikutnya. Menurut Setyo dan Harmini, (2012:113) keterampilan memcahkan masalah perlu dilatihkan sejak dini, agar siswa SD memiliki keterampilan dalam pemecahan masalah terutama pemecahan masalah yang berkaitan dengan Matematika. Akan tetapi guru juga harus memiliki strategi agar pemecahan masalah Matematika menjadi pembelajaran yang disukai siswa. Peran guru dalam kurikulum 2013 adalah sebagai fasilitator dan motivator. Fasilitator yang berarti memfasilitasi siswa untuk dapat memecahkan masalah Matematika. Dan motivator berarti memotivasi siswa agar lebih giat belajar. Maka dari itu perlu diterapkan model pembelajaran yang mendukung proses pemecahan masalah. Bukan hanya itu guru juga memerlukan media pembelajaran yang menarik agar siswa tertarik mengikuti pembelajaran Matematika.

Berdasarkan hasil dan wawancara di kelas IV SDN Sidorejo Kidul 02 pada mata pelajaran Matematika didapatkan bahwa siswa yang kurang mampu melatih keterampilan pemecahan masalah yang dimiliki. Berdasarkan keterangan dari guru, siswa mampu menyelesaikan soal Matematika dengan cara dibimbing. Siswa mampu menyelesaikan soalsoal yang penyelesaiaanya membutuhkan hafalan rumus Matematika. Mereka belum mampu mengasah pengetahuan dan keterampilannya untuk menyelesaikan soal Matematika dalam bentuk soal cerita, kegiatan pembelajaran yang dilakukan belum menggunakan hal-hal yang berbasis masalah dan siswa tidak menyelesaikan suatu masalah dengan caranya sendiri melainkan meniru contoh yang diberikan guru. Penyebab lain adalah proses pembelajaran masih menggunakan metode ceramah memberikan tugas dan terkadang melakukan tanya jawab dengan siswa. Selain itu kemampuan siswa dalam menyelesaikan soal Matematika masih rendah. Hal tersebut dibuktikan dengan hasil belajar siswa pada saat ulangan harian kemampuan pemecahan masalah yang belum mencapai Kriteria Ketuntasan Minimal (KKM) 
Matematika 70. Dari 23 siswa hanya $39 \%$ yang mencapai nilai KKM. Keadaan seperti ini seharusnya segera diatasi, baik dengan cara menindak lanjuti kinerja siswa ataupun model pembelajaran yang digunakan pada saat proses pembelajaran Matematika berlangsung. Untuk mengatasi permasalahan tersebut dibutuhkan suatu model pembelajaran yang menyenangkan dan menarik bagi siswa sehingga dapat meningkatkan kemampuan pemecahan masalah Matematika.

Adapun indikator pemecahan masalah adalah menurut Rosdianwinata (2015:3) adalah (1) Memahami masalah (understanding the problem) (2) Merencanakan masalah (devising a plan) (3) Menyelesaikan masalah (carrying out the plan) (4) Memeriksa kembali hasil (looking back) Dengan menggunakan model pembelajaran yang tepat maka keterampilan pemecahan masalah akan meningkat. Salah satu model yang melibatkan siswa dalam pemecahan masalah adalah Problem Based Learning (PBL). Model Problem Based Learning (PBL) merupakan sebuah model pembelajaran yang menggunakan pendekatan pembelajaran pada suatu masalah autentik sehingga siswa dapat merangkai pengetahuannya sendiri, mengembangkan keterampilan yang lebih tinggi, membuat siswa lebih mandiri dan membuat siswa percaya diri (Hosnan, 2014:295). Adapun karakteristik pembelajaran Problem Based Learning menurut Sumartini (2018:150) adalah (1) ketergantungan pada masalah, (2) masalahnya benar-benar ill-structured (3) guru hanya bertindak sebagai fasilitator (4) siswa hanya diberikan petunjuk bagaimana menyelesaikan masalah. Menurut Indarwati, Wahyudi \& Ratu (2014:23-24) menyebutkan langkah-langkah penerapan Problem Based Learning (PBL) adalah sebagai berikut: (1) perencanaan, yang mencakup beberapa hal seperti mempersiapkan siswa untuk dapat berperan self-directed

problem solvers yang dapat berkolaborasi dengan pihak lain, menghadapkan siswa pada untuk mampu menemukan masalahnya, dan meneliti hakikat permasalahan yang dipersiapkan sambil mengajukan dugaan-dugaan serta rencana penyelesaian masalah (2) Penyelidikan, meliputi kegiatan mengeksplorasi berbagai cara menjelaskan kejadian serta implikasinya dan mengumpulkan serta mendistribusikan informasi. (3) Penyajian hasil yaitu menyajikan temuantemuan. (4) Mengembangkan dan menyajikan hasil karya/diskusi. Pada tahap ini guru membantu siswa dalam merencanakan dan menyiapkan karya yang sesuai seperti laporan, model dan membantu mereka untuk berbagi tugas dengan temannya, dan (5) Tanya jawab/diskusi yang meliputi kegiatan menguji kelemahan dan keunggulan solusi yang dihasilkan, dan melakukan refleksi atas efektivitas seluruh pendekatan yang telah digunakan dalam penyelesaian masalah.

\section{Metode}

Jenis penelitian ini merupakan Penelitian Tindakan Kelas (PTK). Subyek penelitian ini adalah siswa kelas IV SD Negeri Sidorejo Kidul 02, dengan jumlah siswa 23 Rancangan penelitian yang digunakan dalam penelitian ini adalah model spiral yang dikemukakan oleh Kemmis \& MC Taggart dimana setiap siklus terdiri dari 4 tahap yaitu perencanaan, pelaksanaan, observasi, serta refleksi (Saputra, 2016: 3). Teknik pengumpulan data dalam penelitian meliputi tes, rubrik penilaian, observasi dan dokumentasi. Tes berupa tes objektif yang terdiri dari 15 soal yang diberikan diakhir setiap siklusnya. Sedangakan observasi pada penelitian ini dilakukan untuk mengamati tindakan guru dalam menerapkan model pembelajaran Problem Based Learning dan respon siswa dalam menerima pembelajaran.

\section{Hasil dan Pembahasan}

Pada bagian ini, akan dipaparkan hasil analisis dan data penelitian tentang hasil belajar Matematika pada siswa kelas IV di SDN Sidorejo Kidul 02 dengan menggunakan metode Problem Based Learning. Keterampilan Pemecahan masalah Matematika siswa dari pra siklus, siklus I, dan siklus II dapat dilihat pada tabel 1 di bawah ini: 
Tabel 1 Peningkatan Keterampilan Pemecahan Malasah Matematika kelas IV SD Negeri Sidorejo Kidul 02

\begin{tabular}{ccccccccc}
\hline No & Ketuntasan & KKM & \multicolumn{2}{c}{ Kondisi Awal } & \multicolumn{2}{c}{ Siklus I } & \multicolumn{2}{c}{ Siklus II } \\
& Belajar & & $F$ & $\%$ & $F$ & $\%$ & $F$ & $\%$ \\
\hline 1 & Tuntas & $\leq 70$ & 9 & $39 \%$ & 15 & $65 \%$ & 21 & $91 \%$ \\
2 & Tidak Tuntas & $<70$ & 14 & $61 \%$ & 8 & $35 \%$ & 2 & $9 \%$ \\
& Total & & 23 & $100 \%$ & 23 & $100 \%$ & 23 & $100 \%$ \\
& Rata-Rata & & \multicolumn{2}{c}{64,30} & \multicolumn{2}{c}{74,21} & \multicolumn{2}{c}{82,86} \\
\hline
\end{tabular}

Berdasarkan tabel di atas dapat dilihat bahwa telah terjadi peningkatan keteampilan pemecahan masalah meningkat secara bertahap. Pada kegiatan pra siklus menunjukan bahwa siswa yang tuntas hanya 9 peserta didik saja (39\%) dari keseluruhan siswa, sedangkan yang tidak tuntas adalah 14 siswa (61\%) yang tidak mencapai KKM yang telah dintentukan yaitu 70 . Pada kegiatan siklus I siswa yang tuntas meningkat menjadi 15 siswa atau (65\%) sedangkan yang tidak tuntas terdapat 8 siswa (35\%). Pada siklus II peserta didik yang tuntas cukup banyak yaitu mencapai 21 siswa $(91 \%)$ dan sisanya hanya 2 siswa yang tidak tuntas $(9 \%)$. Dengan demikian pembelajaran dengan menggunakan model pembelajaran Problem Based Learning dapat meningkatkan keterampilan pemecahan masalah Matematika kelas IV di SDN Sidorejo Kidul 02. Peningkatan kegiatan pemecahan masalah siswa dapat dilihat pada tabel di bawah ini:

Tabel 2 Peningkatan kegiatan pemecahan masalah siswa

\begin{tabular}{cc}
\hline Siklus I & Siklus II \\
\hline $75 \%$ & $100 \%$ \\
\hline
\end{tabular}

Berdasarkan tabel diatas peningkatan kegiatan pemecahan masalah siswa pada siklus I dari 4 indikator hanya satu yang belum terlaksana atau mencapai $75 \%$. Sedangkan pada siklus II mencapai $100 \%$ atau semua telah dilaksanakan. Peningkatan aktivitas guru dan siswa dapat dilihat pada tabel di bawah ini:

Tabel 3 Peningkatan aktivitas Guru dan siswa

\begin{tabular}{ccc}
\hline Tindakan & Siklus I & Siklus II \\
\hline Aktivitas Guru & $80 \%$ & $100 \%$ \\
Aktivitas Siswa & $75 \%$ & $100 \%$ \\
\hline
\end{tabular}

Berdasarkan tabel diatas dapat diketahui bahwa peningkatan juga terjadi pada aktivitas guru dan siswa. Penigkatan aktivitas guru dari siklus I dengan presentase $80 \%$ meningkat menjadi $100 \%$ pada siklus II. Begitu juga pada aktivitas siswa. Pada siklus I menunjukan presentase $75 \%$ dan meningkat menjadi $100 \%$ pada siklus II.

Berdasarkan hasil observasi yang telah dilakukan oleh peneliti di kelas IV SDN Sidorejo Kidul 02, diketahui bahwa sebelum tindakan penelitian dilaksanakan pembelajaran yang diterapkan oleh guru masih menggunakan metode ceramah, guru menilai pembelajaran menggunakan metode ceramah lebih praktis dari pada menggunakan model pembelajaran inovatif yang memerlukan banyak persiapan lebih di dalam pelaksanaannya. Pemanfaatan media dalam pembelajaran juga masih jarang dilakukan oleh guru, guru merasa kurang terampil dalam menggunakan media pembelajaran sehingga dalam melaksanakan kegiatan pembelajaran guru mengesampingkan pemanfaatan sebuah media, padahal sebuah media pembelajaran dapat menambah ketertarikan siswa dan membantu guru dalam meningkatkan pemahaman siswa terhadap materi. Proses pembelajaran yang diterapkan oleh guru kelas IV SDN Sidorejo Kidul 02 yang menyebabkan siswa kelas IV pasif di dalam proses pembelajaran, tidak ada aktivitas belajar yang bermakna bagi siswa untuk membangun sebuah konsep materi, 
kegiatan dalam pembelajaran masih didominasi oleh guru sehingga dalam pelaksanaan pembelajaran terkesan monoton dan tidak menyenangkan. Hal ini terbukti pada keterampilan pemecahan masalah Matematika pada kondisi awal hanya sebesar 39\% dan sisanya $61 \%$ siswa belum memiliki keterampilan pemecahan masalah Matematika.

Berdasarkan kondisi yang demikian maka perlu adanya tindakan perbaikan pembelajaran untuk meningkatkan keterampilan pemecahan masalah Matematika siswa kelas IV SDN Sidorejo Kidul 02 dengan menerapkan model pembelajaran inovatif yaitu model Problem Based Learning berbantuan media realia. Pada siklus I keterampilan pemecahan masalah Matematika siswa meningkat menjadi $65 \%$ sedangkan yang belum memliki keterampilan pemecahan masalah sebesar $35 \%$. Aktivitas guru pada siklus I sebesar $80 \%$ dan aktivitas siswa sebesar $75 \%$. Peningkatan ini terjadi karena siswa mulai memahami konsep pemecahan masalah Matematika. dan guru menggunakan media realia yang dapat membatu siswa memahami konsep pemecahan masalah Matematika. Akan tetapi peningkatan yang terjadi pada siklus I belum memenuhi target indikator kinerja yang telah ditetapkan yaitu $80 \%$ dari 23 siswa, maka dilanjutkan pada siklus II. Pada siklus I dari 25 aspek observasi aktivitas guru, 5 aspek belum tersampaikan, sedangkan dari 12 aspek lembar observasi siswa, 3 aspek belum tersampaiakan. Dan guru kurang mengkondisikan siswa sehingga berdampak pada sebagian siswa yang berbicara dengan teman sebangku dan mengganggu teman yang lain. Kegiatan pemecahan masalah siswa memiliki presentase sebesar $75 \%$, dari empat indikator hanya satu indikator yang belum terlaksana yaitu memeriksa kembali sesuai dengan hasil penyelesaian masalah.

Perbaikan yang telah dilaksanakan pada siklus I sesuai dengan rencana berdasarkan refleksi yang dikalakukan didapatkan hasil yang lebih baik. Pada siklus II keterampilan pemecahan masalah Matematika siswa meningkat menjadi $91 \%$ sedangkan yang belum memliki keterampilan pemecahan masalah hanya sebesar 9\%. Aktivitas guru pada siklus II mencapai $100 \%$ dan aktivitas siswa sebesar $100 \%$. Kegiatan pemecahan masalah siswa juga mengalami peningkatan sebesar $100 \%$. Peningkatan ini terjadi karena siswa mulai memahami konsep pemecahan masalah Matematika. dan guru menggunakan media realia yang dapat membatu siswa memahami konsep pemecahan masalah Matematika. Berdasarkan pengamatan selama pelaksanaan tindakan pembelajaran pada siklus I dan siklus II terlihat rata-rata kemampuan pemecahan masalah Matematika semakin baik dan mengalami peningkatan pada setiap siklusnya. Siswa lebih antusias dan aktif mengikuti setiap proses pembelajaran, lebih berani di dalam menyampaikan gagasan dan melakukan kegiatan tanya jawab bersama guru, dengan penerapan model Problem Based Learning berbantuan media realia. Pembelajaran yang berlangsung menjadi lebih menarik dan bermakna bagi siswa, proses pembelajaran tidak hanya terpusat pada guru melainkan siswa juga ikut terlibat dalam proses pembelajarannya.

Pemanfaatan media dalam pembelajaran menambah manfaat dari pelaksanaan PTK ini, adanya media membuat siswa dapat berpikir secara konkrit tentang materi disampaikan guru. Selain itu dengan model Problem Based Learning berbantuan media realia siswa mampu mengidentifikasi materi dan mampu memecahkan permasalahan yang ada dalam pembelajaran muatan Matematika. Dapat dikatakan bahwa model Problem Based Learning berbantuan media realia dapat meningkatkan aktivitas belajar secara kognitif, hal ini ditunjukan dengan meningkatnya keterampilan pemecahan masalah Matematika, siswa kelas IV SDN Sidorejo Kidul 02 setelah dilaksanakannya tindakan penelitian menggunakan model Problem Based Learning berbantuan media realia.

Berdasarkan hasil penelitian diatas membuktikan bahwa guru tepat memilih model pembelajaran. Hal ini sependapat dengan temuan peneliti lain seperti yang dilakukan oleh Suwandi (2015) menyatakan bahwa model pembelajaran PBL dapat meningkatkan hasil belajar siswa dan proses pembelajaran yang kondusif, aktif, kreatif, dan menyenangkan pada pembelajaran hubungan makhluk hidup dalam ekosistem. Wahyudi (2013) penggunaan model pembelajaran PBL dan word square dapat meningkatkan aktivitas siswa, aktivitas guru, dan hasil belajar konsep sifat -sifat cahaya pada siswa kelas V SDN Pemurus Dalam 7 
Banjarmasin. Indah (2015) menyatakan bahwa model pembelajaran PBL dapat meningkatkan prestasi belajar IPA materi pokok sumber energi gerak pada siswa kelas IA SDN 9 Kabangka Tahun ajaran 2014/2015. Menurut Syafriana (2016) penerapan model pembelajaran PBL dalam pendekatan saintifik meningkatkan hasil belajar siswa pada pelajaran IPA kelas 5 SDN Surabaya. Hidayat (2016) menyatakan bahwa model pembelajaran PBL meningkatkan hasil belajar siswa kelas 5B SDN 1 Cakranegara tahun ajaran 2015/2016.

Berdasarkan uraian penelitian, maka penerapan model Problem Based Learning berbantuan media realia dapat meningkatkan keterampilan pemecahan masalah Matematika pada siswa kelas IV Semester I SDN Sidorejo Kidul 02 Tahun Pelajaran 2016/2017. Hal ini disebabkan karena siswa belajar tentang pemecahan masalah Matematika secara sistematis melalui langkah-langkah pembelajaran Problem Based Learning. Model Problem Based Learning pembelajaran yang berfokus pada pemberian masalah untuk dipecahkan oleh siswa. Masalah yang diajukan guru adalah masalah nyata sehingga siswa dilatih untuk memecahkan masalah secara sitematis. Sehingga siswa dapat mengkonstruksi pengetahunnya sendiri.

\section{Simpulan dan Saran}

Berdasarkan analisis tindakan hasil penelitian yang telah dilakasanakan di kelas IV SDN Sidorejo Kidul 02 maka dapat disimpulkan bahwa melalui penerapan model pembelajaran Problem Based Learning berbantuan media realia dalam pembelajaran Matematika dapat meningkatkan keterampilan pemecahan masalah Matematika pada kelas IV semester 1 SDN Sidorejo Kidul 02 Tahun Pelajaran 2018/2019. Pada kondisi awal mula-mula nilai keterampilan pemecahan masalah Matematika sebesar 39\% dan sisanya $61 \%$ siswa belum memiliki keterampilan pemecahan masalah Matematika. Kemudian setelah pelaksanaan tindakan siklus I dengan menerapkan model pembelajar Problem Based Learning, keterampilan pemecahan masalah Matematika siswa meningkat menjadi $65 \%$ sedangkan yang belum memliki keterampilan pemecahan masalah sebesar $35 \%$. Aktivitas guru pada siklus I sebesar $80 \%$ dan aktivitas siswa sebesar $75 \%$. Kemudian setelah pelaksaan tindakan pembelajran pada siklus II keterampilan pemecahan masalah Matematika siswa meningkat menjadi $91 \%$ sedangkan yang belum memliki keterampilan pemecahan masalah hanya sebesar 9\%. Aktivitas guru pada siklus II mencapai $100 \%$ dan aktivitas siswa sebesar $100 \%$.

Berdasarkan simpulan di atas, maka saran yang dapat diajukan dalam penelitian adalah sebagai berikut : (1) Guru hendaknya lebih kreatif dalam mengembangkan metode dan model pembelajaran. (2) Guru diharapkan mampu menciptakan media pembelajaran yang kreatif bagi siswa. (3) Guru mampu menjadi fasilitator dan motivator untuk membangkitkan minat belajar pada siswa dan membimbing siswa mengkonstruksi pengetahuannya sendiri. (3) Guru sebagai kunci di dalam perencanaan sebuah pembelajaran hendaknya dapat menciptakan pembelajaran dengan menerapkan model pembelajaran yang inovatif sehingga mampu menciptakan suasana pembelajaran yang menyenangkan dan tidak monoton, siswa dapat lebih antusias dan bersemangat di dalam mengikuti setiap proses pembelajaran yang berlangsung. Kondisi yang demikian juga menunjang di dalam upaya guru untuk mengembangkan kurikulum di tingkat kelas.

\section{Daftar Pustaka}

Faizah, U. (2015). Penerapan Pendekatan Saintifik melalui Model Project Based Learning untuk Meningkatkan Keterampilan Proses dan Hasil Belajar Siswa Kelas IV SD N Serowan Wonosegoro. Scholaria. 5 (1), 28.

Hidayat, W. (2016). Penerapan Model Problem Based Learning Untuk Meningkatkan Hasil Belajar Ipa Siswa Kelas Vb Sdn 1 Cakranegara Tahun Ajaran 2015/2016. 1 - 14.

Hartono, \& Yusuf. (2014). Matematika: Stategi Pemecahan Masalah. Yogyakarta: Graha Ilmu. 
Hosnan , M. (2014). Pendekatan Scintific dan Konstektual dalam Pembelajaran Abad 21. Bogor: Ghalia Indonesia.

Indarwati, D. Wahyudi \& Ratu N (2014) Peningkatan Kemampuan Pemecahan Masalah Matematika Melalui Penerapan Problem Based Learning untuk Siswa Kelas V SD. Satya Widya: Jurnal Penelitian Pengembangan Kependidikan, 30, 17.

Indah, N. (2015). Meningkatkan Prestasi Belajar IPA Materi Pokok Sumber Energi Gerak Melalui Penerapan Model Pembelajaran Problem Based Learning (PBL) Pada Siswa Kelas I.A SD Negeri 9 Kabangka Tahun Ajaran 2014/2015. 50 - 55.

Kemendikbud. (2016). Permendikbud No 21 Tahun 2016 tentang standar Isi Sekolah dasar dan Menengah. Jakarta: Kementrerian Pendidikan dan Kebudayaan.

Rahmadani, N., \& Anugraheni, I. (2017). Peningkatan aktivitas belajar matematika melalui pendekatan problem based learning bagi siswa kelas 4 SD. Scholaria: Jurnal Pendidikan Dan Kebudayaan, 7 (3), 241-250.

Rosdianwinata, E. (2015). Penerapan Metode Discovery Untuk Meningkatkan Kemampuan Pemecahan Masalah Matematika Siswa. MENDIDIK: Jurnal Kajian Pendidikan Dan Pengajaran, 1(1), 1-8.

Saputra, Y. E., \& Slamet, S. (2016). PENERAPAN MODEL PEMBELAJARAN PROJECT BASED LEARNING (PJBL) UNTUK MENINGKATKAN KEAKTIFAN DAN HASIL BELAJAR PEREKAYASAAN SISTEM KONTROL SISWA KELAS XII EI 3 SMK N 3 WONOSARI. E-JPTE (Jurnal Elektronik Pendidikan Teknik Elektronika), 5(3), 55-60.

Sumartini, T. S. (2018). Peningkatan Kemampuan Pemecahan Masalah Matematis Siswa melalui Pembelajaran Berbasis Masalah. Mosharafa: Jurnal Pendidikan Matematika, 5(2), 148-158.

Setyo , E., \& Harmini, S. (2012). Matematika untuk PGSD. Bandung: PT Remaja Rosdakarya.

Suwandi, Y. (2015). Peningkatan Hasil Belajar IPA Tentang Ekosistem Melalui Metode Problem Based Learning Pada Siswa Kelas V Sekolah Dasar Kabupaten Tana Tidung. Jurnal Pendidikan Dasar Volume 6 Edisis 1 mei 2015, 93 - 102.

Syafriana, D. (2016). Penerapan Model Problem Based Learning (Pbl) Dalam Pendekatan Saintifik Untuk Meningkatkan Hasil. Jurnal Inovasi Pendidikan Dan Pembelajaran Sekolah Dasar, 30 - 43.

Wahyudi, M. D. (2013). Meningkatkan Hasil Belajar Konsep Sifat - Sifat Cahaya Menggunakan Model Pembelajaran Problem Based Learning (PBL) Dan Word Square Pada Siswa Kelas V SDN Pemurus Dalam 7 Banjarmasin. Jurnal Paradigma Volume 8 Nomor 1 Januari - Juni 2013, 1 -7. 